\title{
NUCLEAR ENGINEERING Enrollments and Degrees Decreased at all Levels in 1997
}

\section{SURVEY UNIVERSE}

The survey of "Nuclear Engineering Enrollments and Degrees, 1997" was sent to 46 institutions offering a major in nuclear engineering or an option program in another discipline or department (for example, electrical or mechanical engineering) equivalent to a major that qualifies the graduates to perform as nuclear engineers. Of the 46 institutions surveyed, 1 program was inactive, 3 programs were suspended but allowing the students to complete their degrees, and the data for 1 program were estimated.

\section{UNDERGRADUATE ENROLLMENTS AND DEGREES}

Nuclear engineering undergraduate enrollments decreased by 28 percent from 1996 (by 128 full-time, 85 part-time students), continuing the downward trend since 1992. The decrease was attributed to the suspended programs and a decline overall among the other programs. (Figure 1.) Sixty-six percent of the 570 students were enrolled in the nuclear engineering major. Among the option programs, mechanical engineering accounted for 6 percent of the total, or 32 students.

Figure 1. Nuclear Engineering Undergraduate Enrollments and Degrees, 1987-1997

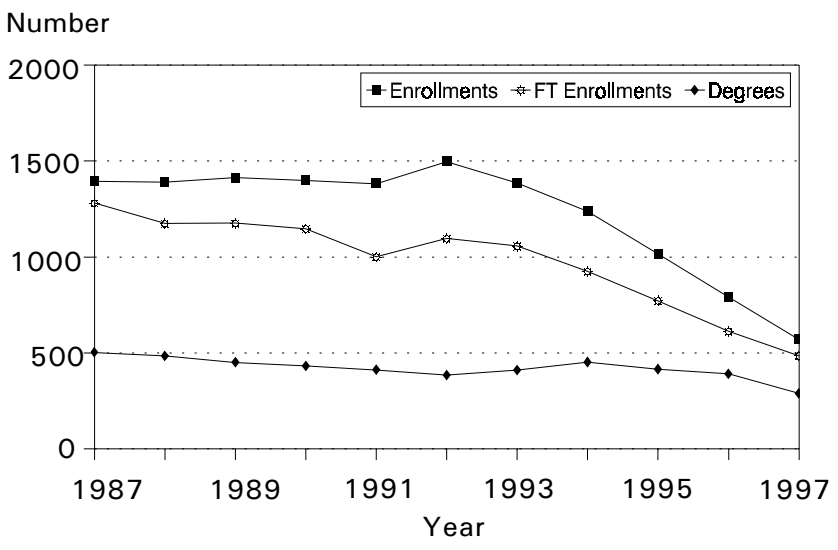

Undergraduate $=$ Junior and Senior Level. Source: U.S. Department of Energy.
Undergraduate degrees decreased by 26 percent or 101 students in 1997. Sixty-one percent (176 students) received their degrees within the nuclear engineering major programs. The second highest number of degrees were awarded within the mechanical engineering option programs (7 percent or 21 students).

\section{MASTER'S ENROLLMENTS AND DEGREES}

Master's enrollments continued the downward trend and decreased by 10 percent, or by 35 full-time and 11 part-time students, from 1996. (Figure 2.) Ninety-nine percent, or 457 students, were enrolled in the nuclear engineering major programs.

Figure 2. Nuclear Engineering Master's Enrollments and Degrees, 1987-1997

Number

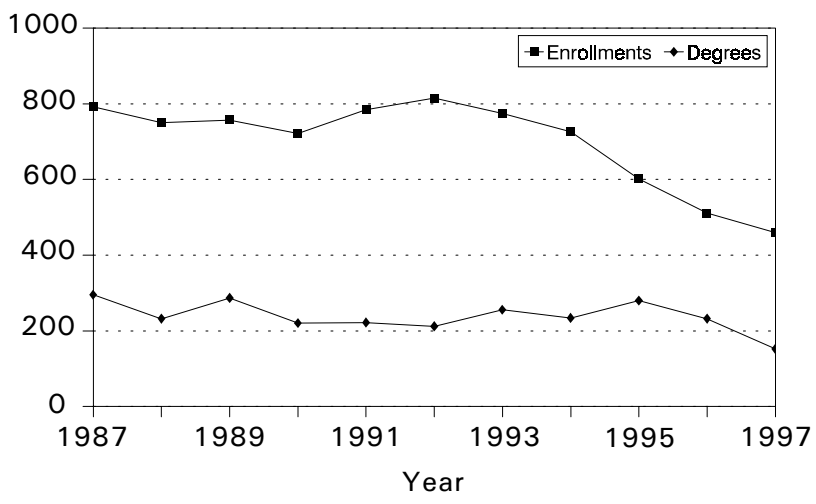

Source: U.S. Department of Energy.

Nuclear engineering master's degrees decreased in 1997 by 34 percent ( 80 students), continuing a downward trend since 1995. All of the 152 students received their degrees within the nuclear engineering major programs.

\section{DOCTORAL ENROLLMENTS AND DEGREES}

Doctoral enrollments declined from 537 students to 490, or by 9 percent, which is about the same percent of decrease each year since 1993. (Figure 3.) About 99 percent of the students (398 full-time and 90 part-time) were enrolled in the nuclear engineering major programs. 
Figure 3. Nuclear Engineering Doctoral Enrollments and Degrees, 1987-1997

Number

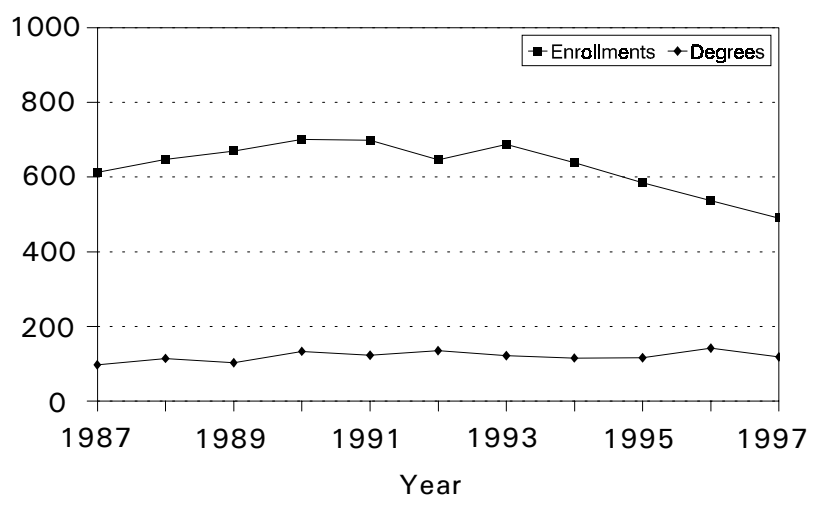

Source: U.S. Department of Energy.

The number of nuclear engineering doctorates decreased from 141 to 118 students in 1997, a decrease of 16 percent from 1996, but about the average annual number of degrees awarded over the last 15 years. The majority of the degrees were awarded within the nuclear engineering major (105 students), and 7 students received their degrees within the mechanical engineering option programs.

\section{NUCLEAR ENGINEERING COMPARED WITH ALL ENGINEERING DEGREES}

As a percent of "all engineering" degrees (data provided by the Engineering Workforce commission of the American Association of Engineering Societies, Washington, DC), nuclear engineering degrees (both majors and option programs) represented less than 1 percent of the undergraduate and master's degrees and just under 2 percent for the doctorates in 1997.

\section{EMPLOYMENT OR POSTGRADUATION PLANS}

The largest portion of the undergraduates (about one-fourth or 76 students) were working in nuclear utilities, while 22 percent ( 65 students) elected to continue study for a higher degree. (Table 1.) About a third of the master's graduates (51 students) were continuing study, and 21 percent were working in U.S. industry. Twenty percent of the doctorates were working in U.S. industry, while continued study, academia, and DOE contractors accounted for 12 percent each.
Table 1. Employment or Postgraduation Plans of Nuclear Engineering Graduates by Degree Level, 1997 (Percent Distribution)

\begin{tabular}{lccc}
$\quad$ Employment or & & \\
Postgraduation Plans & B.S. & M.S. & Ph.D. \\
\hline Continued study & $22 \%$ & $34 \%$ & $12 \%$ \\
U.S. academic employ. & 1 & 3 & 12 \\
Federal gov. employ. & 2 & 7 & 9 \\
DOE contractors (M\&Os) & 1 & 2 & 12 \\
State and local gov. employ. & 0 & 0 & 2 \\
U.S. nuclear utility employ. & 26 & 10 & 5 \\
U.S. other industrial employ. & 14 & 21 & 20 \\
Employ. with foreign employ. & 1 & 5 & 8 \\
U.S. military service & 12 & 5 & 3 \\
Other/seeking employ. & 2 & 3 & 8 \\
Unknown & 18 & 11 & 10 \\
TOTALS & $100 \%$ & $100 \%$ & $100 \%$ \\
NOTE: Percentages are rounded to nearest whole number. & \\
Source: U.S. Department of Energy. &
\end{tabular}

\section{FOREIGN NATIONAL AND MINORITY PARTICIPATION}

Degrees awarded to foreign nationals decreased at all levels in 1997; bachelor's from 11 in 1996 to 8 students, master's from 57 to 39, and doctorates from 65 to 42. Two of the foreign national bachelor's went to work for a foreign employer, 22 of the master's were continuing study for a higher degree, and 14 of the 42 new doctorates went to work with a foreign employer. (See Table 2 for percent distribution of foreign nationals.)

\section{Table 2. Percentage of Nuclear Engineering Degrees Awarded to Foreign Nationals, 1993-1997}

\begin{tabular}{cccc} 
Year & B.S. & M.S. & Ph.D. \\
\hline 1993 & 2 & 29 & 55 \\
1994 & 3 & 24 & 52 \\
1995 & 5 & 24 & 49 \\
1996 & 3 & 25 & 46 \\
1997 & 2 & 26 & 36
\end{tabular}

Source: U.S. Department of Energy.

Minority participation (excluding foreign nationals) in nuclear engineering programs remained low (within the 1 to 3 percent range overall in 1997). The number of African Americans and Hispanic Americans increased in number slightly at the bachelor's level, while Asian Americans decreased at the bachelor's level from 17 to 10 students. (NOTE: In 1997, ethnicity data were collected for degrees only.) 
Table 3. Nuclear Engineering Enrollments and Degrees, by State and Institution, 1997

\begin{tabular}{|c|c|c|c|c|c|c|c|}
\hline \multirow{2}{*}{ State } & \multirow[b]{2}{*}{ Institution } & \multicolumn{3}{|c|}{ Enrollments } & \multicolumn{3}{|c|}{ Degrees } \\
\hline & & Undergraduate & Master's & Doctoral & B.S. & M.S. & Ph.D. \\
\hline ARIZONA & University of Arizona ${ }^{1}$ & 12 & 4 & 5 & 4 & - & \\
\hline ARKANSAS & University of Arkansas & 2 & 1 & - & 1 & - & \\
\hline \multirow[t]{2}{*}{ CALIFORNIA } & University of California, Berkeley & 30 & 25 & 27 & 10 & 11 & \\
\hline & University of California, Los Angeles ${ }^{2}$ & - & - & 4 & - & 1 & \\
\hline FLORIDA & University of Florida, Gainesville & 21 & 15 & 5 & 9 & 4 & \\
\hline GEORGIA & Georgia Institute of Technology & 13 & 8 & 25 & 10 & 4 & \\
\hline \multirow{2}{*}{ IDAHO } & Idaho State University & 4 & 10 & 9 & 1 & 1 & \\
\hline & University of Idaho* & - & 2 & 6 & - & 1 & \\
\hline ILLINOIS & University of Illinois, Urbana & 24 & 25 & 20 & 7 & 4 & \\
\hline \multirow[t]{2}{*}{ INDIANA } & Purdue University & 21 & 20 & 17 & 10 & 9 & \\
\hline & University of Notre Dame & 4 & - & - & 5 & - & \\
\hline IOWA & lowa State University & - & - & 1 & - & 1 & \\
\hline KANSAS & Kansas State University & 15 & 4 & 5 & 5 & 2 & \\
\hline LOUISIANA & Louisiana State University & - & 4 & 3 & - & - & \\
\hline MAINE & University of Maine & 3 & - & - & 3 & - & \\
\hline \multirow[t]{3}{*}{ MARYLAND } & U.S. Naval Academy & 24 & - & - & 18 & - & \\
\hline & University of Maryland & 8 & 11 & 30 & 10 & 6 & \\
\hline & University of Maryland, Univ. College & 77 & - & - & 50 & - & \\
\hline \multirow{3}{*}{ MASSACHUSETTS } & Massachusetts Institute of Technology & 14 & 57 & 46 & 3 & 17 & 13 \\
\hline & University of Massachusetts Lowell & 14 & 5 & 1 & - & 1 & \\
\hline & Worcester Polytechnic Institute & 7 & - & - & 8 & - & \\
\hline MICHIGAN & University of Michigan, Ann Arbor & 21 & 24 & 48 & 14 & 11 & 15 \\
\hline MISSOURI & University of Missouri, Columbia & - & 7 & 7 & - & 1 & \\
\hline NEW MEXICO & University of Missouri, Rolla & 27 & 10 & 7 & 10 & 1 & \\
\hline \multirow[t]{7}{*}{ NEW YORK } & University of New Mexico & 7 & 27 & 24 & 4 & 2 & \\
\hline & Clarkson University** & - & - & - & - & - & \\
\hline & Columbia University & - & - & 4 & - & - & \\
\hline & Cornell University & - & 1 & 3 & - & 5 & \\
\hline & Manhattan College ${ }^{2}$ & 1 & - & - & - & - & \\
\hline & Rensselaer Polytechnic Institute & 21 & 10 & 28 & 16 & 8 & \\
\hline & U.S. Military Academy & 18 & - & - & 6 & - & \\
\hline NORTH CAROLINA & North Carolina State University & 29 & 20 & 19 & 8 & 7 & \\
\hline \multirow{4}{*}{ OHIO } & Air Force Institute of Technology & - & 13 & 3 & - & - & \\
\hline & Ohio State University & 7 & 16 & 14 & - & 10 & \\
\hline & University of Cincinnati & 7 & 11 & 18 & 4 & 9 & \\
\hline & Youngstown State & 6 & - & - & 4 & - & \\
\hline OREGON & Oregon State University & 19 & 6 & 5 & 7 & - & \\
\hline PENNSYLVANIA & Pennsylvania State University & 28 & 34 & 20 & 18 & 7 & \\
\hline \multirow[t]{2}{*}{ TENNESSEE } & Tennessee Technological University & 9 & - & - & 5 & - & \\
\hline & University of Tennessee, Knoxville & 14 & 22 & 15 & 7 & 4 & \\
\hline \multirow[t]{2}{*}{ TEXAS } & Texas A\&M University & 30 & 32 & 19 & 9 & 5 & \\
\hline & University of Texas, Austin & - & 9 & 10 & - & 3 & \\
\hline UTAH & University of Utah & 16 & 7 & 6 & 12 & 1 & \\
\hline VIRGINIA & University of Virginia & - & 9 & 6 & - & 5 & \\
\hline WASHINGTON & University of Washington ${ }^{2}$ & - & - & 1 & - & - & 2 \\
\hline \multirow[t]{2}{*}{ WISCONSIN } & University of Wisconsin, Madison & 17 & 11 & 29 & 12 & 11 & \\
\hline & & 570 & 460 & 490 & 290 & 152 & 118 \\
\hline
\end{tabular}

*Estimated.

** Inactive.

NOTES: 'The undergraduate program at the University of Arizona has been suspended; students are being allowed to complete their degrees. ${ }^{2}$ Program suspended; students are being allowed to complete their degrees. 
This report is based on work performed under Contract Number DE-AC05-OR00033 between the U.S. Department of Energy and Oak Ridge Associated Universities.

All opinions expressed in this report are the authors' and do not necessarily reflect policies and views of the U.S. Department of Energy or the Oak Ridge Institute for Science and Education.

Additional survey information, providing details by individual schools and by type of program, is available from:

Oak Ridge Institute for Science and Education

Science and Engineering Education

Analysis and Evaluation Programs

P.O. Box 117

Oak Ridge, TN 37831-0117

Oak Ridge Institute for Science and Education Analysis and Evaluation Programs, MS 36

P.O. Box 117

Oak Ridge, TN 37831-0117

Manpower Brief \# 42 